\title{
Increased incidence of non-Hodgkin's lymphoma in inflammatory bowel disease patients on immunosuppressive therapy but overall risk is low
}

\author{
R J Farrell, Y Ang, P Kileen, D S O’Briain, D Kelleher, P W N Keeling, D G Weir
}

Department of Clinical Medicine and Gastroenterology, St James's Hospital,

Trinity College Dublin, Republic of Ireland

R J Farrell

Y Ang

P Kileen

D Kelleher

P W N Keeling

D G Weir

Department of Histopathology, St James's Hospital, Trinity College Dublin, Republic of Ireland

D S O'Briain

Correspondence to:

Dr R J Farrell,

Gastroenterology Division,

Beth Israel Deaconess

Medical Center, Harvard

Medical School, Dana 501,

330 Brookline Avenue,

Boston, MA 02215, USA.

Email: rfarrell@

caregroup.harvard.edu

Accepted for publication 22 February 2000
Background-There is concern that the incidence of non-Hodgkin's lymphoma (NHL) will rise with increasing use of immunosuppressive therapy.

Aims-Our aim was to determine the risk of NHL in a large cohort of patients with inflammatory bowel disease (IBD), and to study the association between IBD, NHL, and immunosuppressive therapy.

Methods-We studied 782 IBD patients (238 of whom received immunosuppressive therapy) who attended our medical centre between 1990 and 1999 (median follow up 8.0 years). Standardised incidence ratios (SIRs) and $95 \%$ confidence intervals (CI) were calculated. Expected cases were derived from 1995 age and sex specific incidence rates recorded by the National Cancer Registry of Ireland.

Results-There were four cases of NHL in our IBD cohort (SIR 31.2; 95\% CI 2.0-85; $\mathrm{p}=\mathbf{0 . 0 0 0 1 )}$, all of whom had received immunosuppressive therapy: azathioprine $(n=2)$, methotrexate $(n=1)$, and methotrexate and cyclosporin $(n=1)$. Our immunosuppressive group had a significantly (59 times) higher risk of NHL compared with that expected in the general population $(p=0.0001)$. Three cases were intestinal NHL and one was mesenteric. Mean age at NHL diagnosis was 49 years, mean duration of IBD at the time of NHL diagnosis was 3.1 years, and mean duration between initiation of immunosuppressive therapy and diagnosis of NHL was 20 months.

Conclusions-Although underlying IBD may be a causal factor in the development of intestinal NHL, our experience suggests that immunosuppressive drugs can significantly increase the risk of NHL in IBD. This must be weighed against the improved quality of life and clinical benefit immunosuppressive therapy provides for IBD patients.

(Gut 2000;47:514-519)

Keywords: inflammatory bowel disease; non-Hodgkin's lymphoma; immunosuppressive therapy; azathioprine; methotrexate; cyclosporin

The incidence of non-Hodgkin's lymphoma (NHL) is $40-100$ times greater in transplant patients requiring immunosuppressive therapy than in the general population. ${ }^{12}$ While these striking excesses reflect high doses of immunosuppressive drugs required in transplant recipi- ents as well as the need for longer periods of therapy to maintain graft survival, the increasing use of immunosuppressive agents to treat patients with inflammatory bowel disease (IBD) has raised similar worries about the incidence of NHL in IBD patients. Although the association of colorectal cancer with IBD, particularly ulcerative colitis (UC), is well established, the association between IBD and NHL is less clear cut. While there are several reports of intestinal and extraintestinal NHL in patients with longstanding extensive IBD who did not receive immunosuppressive therapy, suggesting an increased incidence of lymphoma and IBD, ${ }^{3-6}$ three IBD population based studies have reported no evidence for a statistically increased risk of NHL ${ }^{7-9}$ However, the power of these studies to detect a significant increase in lymphoma was small. Although a recent study assessing the risk of malignancy in IBD patients receiving azathioprine therapy was reassuring, ${ }^{10}$ it is generally accepted that there is an increased risk of NHL among patients receiving immunosuppressive therapy. ${ }^{11-13}$ Four extraintestinal malignancies, including one case of brain NHL, occurred in 157 Crohn's disease patients receiving azathioprine or 6-mercaptopurine. ${ }^{14}$ Similarly, the recent reporting of eight cases of lymphoproliferative disease among almost 800 rheumatoid arthritis and Crohn's disease patients treated with infliximab, a chimeric antitumour necrosis factor $\alpha$ antibody, has again raised questions about the risk of NHL in IBD in addition to the malignant potential of immunosuppressive agents. ${ }^{15}$ Given the confounding data, we undertook a study to determine the incidence of NHL in a large cohort of IBD patients, approximately one third of whom received immunosuppressive therapy.

\section{Methods}

DATA COLLECTION

An IBD register set up in mid-1996 recorded the clinical details, pharmacotherapy, including immunosuppressive therapy, and complications of 796 IBD patients who attended St James's Hospital, a major tertiary referral centre, between January 1990 and June 1999. The immunosuppressive group were defined as those IBD patients who had ever received azathioprine, 6-mercaptopurine, methotrexate, or cyclosporin or a combination of these agents.

Abbreviations used in this paper: IBD, inflammatory bowel disease; NHL, non-Hodgkin's lymphoma; UC, ulcerative colitis; SIR, standardised incidence ratio. 
Table 1 Demographics of patients with inflammatory bowel disease

\begin{tabular}{ll}
\hline Clinical details & \\
$\mathrm{n}$ & 782 \\
Mean age (y) & $44.1(15.9)$ \\
Sex (M:F) (\% female) & $407: 375(52 \% \mathrm{~F})$ \\
UC:CD & $515: 267(34 \% \mathrm{CD})$ \\
UC extent (E: LS: PS: P) & $35 \%: 27 \%: 23 \%: 15 \%$ \\
CD extent (IC:RE:C) & $48 \%: 35 \%: 17 \%$ \\
Mean duration (y) & $10.01(6.9)$ \\
Median follow up (y) & 8.0 \\
Patient-years of follow up & 6256 \\
Immunosuppressive therapy details & $238(30 \%)$ \\
$\mathrm{n}$ & 6.9 \\
Median follow up (y) & 1642 \\
Patient-years of follow up & 212 \\
Azathioprine (2 mg/kg/day) & 79.3 \\
Mean dose (g) & $1.82 \mathrm{y}(1 \mathrm{mth}$ to $9 \mathrm{y})$ \\
Median duration (range) & 31 \\
Methotrexate (5 mg tiw) & 0.96 \\
Mean dose (g) & $1.8 \mathrm{y}(1 \mathrm{mth}$ to $6 \mathrm{y})$ \\
Median duration (range) & 22 \\
Cyclosporine (2-4 mg/kg/day iv $\pm 4-8$ & \\
mg/kg/day orally) & 147.3 \\
Mean dose (g) & $5 \mathrm{mth}(2 \mathrm{mth}$ to $6 \mathrm{mth})$ \\
Median duration (range) &
\end{tabular}

$\begin{array}{lll}\text { Malignancy } & \text { No of patients } & \begin{array}{l}\text { Incidence } \\ \text { (per } 1000 \text { person-yr } \\ \text { of follow up) }\end{array} \\ \text { All cancers } & 30 & 4.8 / 1000 \\ \text { Colorectal } & 15 & 2.4 / 1000 \\ \text { Lymphoma } & 4 & 0.64 / 1000 \\ \text { Skin } & 7 & 1.1 / 1000 \\ \text { Others } & 4 & 0.64 / 1000\end{array}$

${ }^{\star}$ Per 1000 person-yr of follow up refers to incidence of malignancy. UC, ulcerative colitis, CD, Crohn's disease, E, extensive colitis, LS, left sided colitis; PS, proctosigmoiditis; P, proctitis; IC, ileocolitis; RE, regional enteritis; $\mathrm{C}$, colitis; tiw, three times weekly; iv, intravenous.

All patients on the register were followed up to see if they were alive, if they had ever or were still receiving immunosuppressive drugs, and if they were free from cancer. If immunosuppressive drugs were used, the relevant dates of commencement and termination of therapy as well as dosage were recorded, in addition to any subsequent courses of immunosuppressive therapy. The hospital records and pathology reports of all patients who developed cancer were examined and details of present and past medical history and doses of immunosuppressive drugs used extracted.

DATA ANALYSIS

Fourteen IBD patients $>85$ years were excluded from analysis because of the unreliability of applying reference rates to this open ended age group, leaving 782 patients in our study group (table 1). Observed numbers of deaths from all causes and from all malignancies before the age of 85 and before 1 June 1999 were compared with the numbers expected, calculated by applying national mortality rates specific for age, sex, and calendar period to the corresponding person-years at risk up to age 85 . For comparison, the numbers of all cancer cases, including NHL, among those IBD patients who received immunosuppressive drugs and among those who did not were compared with those expected in the general population by applying the 1995 rates recorded by the National Cancer Registry of Ireland specific for age, sex, and calendar period to the corresponding person-years at risk up to age $85 .{ }^{16}$ The expected number of cases were then added to obtain the total number of expected cancer cases. The relative risk of malignancy was estimated by comparing expected values with the observed numbers of cases and expressed as a standardised incidence ratio (SIR). Calculating 95\% confidence intervals (CI) and assuming a Poisson distribution, differences between the observed and expected values were tested for significance using two sided $t$ tests.

\section{Results}

Patient demographics and details of immunosuppressive therapy are summarised in table 1 . A total of 238 IBD patients (30\%) received immunosuppressive drugs. Two hundred and twelve received azathioprine $(2-2.5 \mathrm{mg} / \mathrm{kg} /$ day $)$ (mean dose $79.3 \mathrm{~g}$ ) for a median of 1.8 years (range one month to nine years) between 1985 and 1999; median follow up was 6.9 years. Thirty one patients received low dose methotrexate $5 \mathrm{mg}$ three times per week (mean dose $0.96 \mathrm{~g}$ ) for a median of 1.24 years (range one month to six years); median follow up was 8.1 years. Twenty two patients received cyclosporin $2-4 \mathrm{mg} / \mathrm{kg} /$ day intravenously and/or $4-8 \mathrm{mg} / \mathrm{kg}$ /day orally (mean dose $143.7 \mathrm{~g}$ ) for a median of five months (range two weeks to six months); median follow up was 6.7 years. Fifteen patients received more than one immunosuppressive agent.

At the end of the study, 715 patients were known to be alive and 20 were lost to follow up. The remaining 47 had died before the age of 85 compared with 40.6 expected; this difference was not significant (observed/expected ratio 1.16 (95\% CI 0.9-1.5); $\mathrm{p}=0.3)$. There were 10 deaths from cancer (three rectum, two colon, one NHL, one skin, one oesophageal, one lung, one pancreas) compared with 2.9 expected (ratio $3.4 ; \mathrm{p}=0.1$ ).

Overall, there was no significant excess of cancer among our IBD population. Thirty IBD patients (19 males, 11 females) developed cancer before age 85 compared with 7.06 expected from national cancer rates in the general population (SIR 4.25; 95\% CI 0.6-14.7; p=0.06). There was a significant difference in the incidence of colorectal cancer $(n=15)$ compared with 0.53 expected (SIR 28.3; 95\% CI $1.7-52.0 ; \mathrm{p}=0.0001)$. Thirteen of these patients had UC and were significantly older (68.9 years $v 49.1$ years; $p<0.001$ ), had more extensive disease $(73 \% v 35.2 \% ; \mathrm{p}<0.001)$, and disease of longer duration (11.7 years $v 6.3$ years; $\mathrm{p}<0.001$ ) compared with UC patients who did not develop colorectal carcinoma.

Overall, there was a significant excess in the incidence of non-Hodgkin's lymphoma $(n=4)$ compared with 0.13 expected (SIR 31.2; $95 \%$ CI 2.0-85; $\mathrm{p}=0.0001)$. All four patients who developed NHL had large B cell malignant lymphoma while receiving immunosuppressive therapy for steroid refractory disease: azathioprine $(n=2)$, methotrexate $(n=1)$, and methotrexate and cyclosporin $(n=1)$. The clinical features and outcome of these four patients are summarised in table 2 and presented briefly below.

The first patient underwent proctocolectomy less than two years after initially presenting with extensive UC, despite five months of methotrexate therapy followed by 12 months of 
Table 2 Clinical features of four patients with non-Hodgkin's lymphoma occurring during the course of inflammatory bowel disease

\begin{tabular}{|c|c|c|c|c|c|c|c|c|c|c|c|c|}
\hline No & Sex & $\begin{array}{l}\text { Age at } \\
\text { onset of } \\
\text { IBD }(y)\end{array}$ & $\begin{array}{l}\text { Age at } \\
\text { onset of } \\
\text { NHL (y) }\end{array}$ & $\begin{array}{l}\text { Interval } \\
\text { between } \\
\text { IBD-NHL } \\
(y)\end{array}$ & $\begin{array}{l}\text { Interval } \\
\text { between } \\
\text { Tx-NHL } \\
\text { (months) }\end{array}$ & $\begin{array}{l}\text { Type of } \\
I B D\end{array}$ & Site of IBD & $\begin{array}{l}\text { Medical therapy of } \\
I B D\end{array}$ & Type of NHL & $\begin{array}{l}\text { Site/stage of } \\
\text { NHL }\end{array}$ & $\begin{array}{l}\text { Therapy } \\
\text { for NHL }\end{array}$ & Outcome \\
\hline 1 & $M$ & 46 & 48 & 2 & 17 & $\mathrm{UC}$ & Extensive & $\begin{array}{l}\text { Salazopyrine, } \\
\text { prednisone, } \\
\text { methotrexate } \\
\text { 1/90-5/90 } 0.27 \mathrm{~g}, \\
\text { cyclosporin } \\
5 / 90-5 / 91274 \mathrm{~g}\end{array}$ & $\begin{array}{l}\text { Large cell } \\
\text { diffuse } \\
\text { B cell } \\
\text { lymphoma }\end{array}$ & $\begin{array}{l}\text { Mesenteric } \\
\text { lymph nodes } \\
\text { stage 1A }\end{array}$ & $\begin{array}{l}\text { Surgical } \\
\text { excision }\end{array}$ & Alive \\
\hline 2 & $M$ & 57 & 61 & 4.5 & 41 & $\begin{array}{l}\text { UC } \\
\text { (PSC) }\end{array}$ & Extensive & $\begin{array}{l}\text { Salazopyrine, } \\
\text { prednisone, } \\
\text { methotrexate } \\
12 / 90-5 / 942.73 \mathrm{~g}\end{array}$ & $\begin{array}{l}\text { Large } \\
\text { pleiomorphic } \\
\text { B cell } \\
\text { lymphoma }\end{array}$ & $\begin{array}{l}\text { Caecal with } \\
\text { rectosigmoid } \\
\text { involvement } \\
\text { stage IVA }\end{array}$ & $\begin{array}{l}\text { Surgical } \\
\text { excision }\end{array}$ & $\begin{array}{l}\text { Died from } \\
\text { postop. sepsis }\end{array}$ \\
\hline 3 & $M$ & 48 & 53 & 4 & 14 & $\mathrm{UC}$ & Proctosigmoid & $\begin{array}{l}\text { Salazopyrine, } \\
\text { prednisone, } \\
\text { azathioprine } \\
4 / 94-5 / 9557 \mathrm{~g}\end{array}$ & $\begin{array}{l}\text { Multifocal } \\
\text { high grade } \\
\text { B cell } \\
\text { lymphoma }\end{array}$ & $\begin{array}{l}\text { Rectum } \\
\text { stage IVA }\end{array}$ & $\begin{array}{l}\text { Surgical } \\
\text { excision+ } \\
\text { chemotx }\end{array}$ & $\begin{array}{l}\text { In remission } \\
\text { for } 3 \mathrm{y}\end{array}$ \\
\hline 4 & $\mathrm{~F}$ & 32 & 34 & 2 & 9 & $\mathrm{CD}$ & Terminal ileum & $\begin{array}{l}\text { Pentasa, } \\
\text { prednisone, } \\
\text { azathioprine } \\
7 / 97-4 / 9833.7 \mathrm{~g}\end{array}$ & $\begin{array}{l}\text { Large cell } \\
\text { diffuse B cell } \\
\text { lymphoma }\end{array}$ & $\begin{array}{l}\text { Ileocaecal } \\
\text { stage III }\end{array}$ & $\begin{array}{l}\text { Surgical } \\
\text { excision+ } \\
\text { chemotx }\end{array}$ & $\begin{array}{l}\text { Mediastinal } \\
\text { recurrence } \\
\text { May } 1999\end{array}$ \\
\hline
\end{tabular}

NHL, non-Hodgkins lymphoma; IBD, inflammatory bowel disease; UC, ulcerative colitis; CD, Crohn's disease; PSC, primary sclerosing cholangitis; chemotx, chemotherapy.

cyclosporin therapy. At laparotomy a $3 \mathrm{~cm}$ indurated gastrocolic omental lymph node was excised and revealed a large cell diffuse B cell type lymphoma. Histological examination of the resected colon and rectum revealed severe pancolitis but no evidence of lymphoma. Physical, bone marrow, and radiological examination revealed no other evidence of lymphoma and no further treatment was required. The patient remains disease free eight years later.

The second patient had early primary sclerosing cholangitis confirmed at liver biopsy and was commenced on methotrexate six months after his initial presentation for steroid refractory proctosigmoiditis. His symptoms were controlled on methotrexate for more than four years until he presented with peritonitis. Laparotomy revealed severe pancolitis and a large locally advanced caecal B cell lymphoma

Table 3 Cancer cases among inflammatory bowel patients (IBD) patients compared with numbers expected from general population rates

\begin{tabular}{|c|c|c|c|c|}
\hline Site & Observed & Expected & O/E Ratio & $p$ Value * \\
\hline \multicolumn{5}{|l|}{ All IBD patients $(n=782)$} \\
\hline Colon & 7 & 0.34 & 20.6 & 0.0001 \\
\hline Rectum & 8 & 0.19 & 42.1 & 0.0001 \\
\hline Non-Hodgkin's lymphoma & 4 & 0.13 & 31.2 & 0.0001 \\
\hline Basal cell carcinoma & 5 & 1.0 & 5 & 0.045 \\
\hline Squamous cell carcinoma & 1 & 0.46 & 2.2 & 0.24 \\
\hline Melanoma & 1 & 0.15 & 6.6 & 0.03 \\
\hline Other neoplasms $\dagger$ & 4 & 4.77 & 0.84 & 0.32 \\
\hline All neoplasms & 30 & 7.06 & 4.25 & 0.06 \\
\hline \multicolumn{5}{|c|}{ Non-immunosuppressive group $(n=544)$} \\
\hline Colon & 3 & 0.24 & 12.5 & 0.0006 \\
\hline Rectum & 6 & 0.13 & 46.1 & 0.0001 \\
\hline Non-Hodgkin's lymphoma & 0 & 0.09 & - & 0.32 \\
\hline Basal cell carcinoma & 4 & 0.69 & 5.75 & 0.026 \\
\hline Squamous cell carcinoma & 1 & 0.32 & 3.1 & 0.138 \\
\hline Melanoma & 0 & 0.10 & - & 0.32 \\
\hline Other neoplasms & 2 & 3.32 & 0.6 & 0.32 \\
\hline All neoplasms & 16 & 4.91 & 3.26 & 0.012 \\
\hline \multicolumn{5}{|c|}{ Immunosuppressive group $(n=238)$} \\
\hline Colon & 4 & 0.1 & 38.7 & 0.0001 \\
\hline Rectum & 2 & 0.06 & 34.6 & 0.0001 \\
\hline Non-Hodgkin's lymphoma & 4 & 0.06 & 58.8 & 0.0001 \\
\hline Basal cell carcinoma & 1 & 0.31 & 3.29 & 0.113 \\
\hline Squamous cell carcinoma & 0 & 0.14 & - & 0.32 \\
\hline Melanoma & 1 & 0.05 & 21.9 & 0.0001 \\
\hline Other neoplasms & 2 & 1.43 & 1.39 & 0.32 \\
\hline All neoplasms & 14 & 2.15 & 6.52 & 0.016 \\
\hline
\end{tabular}

†One case of testicular teratoma and oesophageal adenocarcinoma, both of whom received immunosuppressive therapy. One case of pancreas neuroendocrine tumour and squamous lung carcinoma, none of whom received immunosuppressive therapy.

*Two sided $\mathrm{p}$ value. with extensive posterior abdominal wall involvement, marked intraperitoneal lymphadenopathy, and a free bowel wall perforation with abscess formation. Prominent histiocytes with inclusion-like nucleoli suggestive of superimposed viral infection were noted, although immunoperoxidase stains were negative for cytomegalovirus. The patient died postoperatively from septicaemia.

The third patient commenced azathioprine for steroid dependent proctosigmoiditis after three years of systemic and topical salazopyrine and prednisone. Remission was achieved on $150 \mathrm{mg}$ daily and he remained well for over a year. His symptoms returned, colonoscopy revealed marked proctosigmoiditis which remained active despite prednisone and azathioprine therapy, culminating a year later in localised perforation of the proximal rectum. Subtotal colectomy in June 1996 revealed a trans-serosal high grade B cell lymphoma originating in the rectosigmoid submucosa invading the pericolic fat. There was evidence of underlying UC at surgical resection with pseudopolyps, cryptitis, and crypt abscess formation in the sigmoid area proximal to the area of lymphoma. There was no evidence of lymphoma outside the perirectal tissues. Following abdominoperineal resection he received chemotherapy (six courses of carboplatin, etoposide, bleomycin) and has been in remission for more than three years.

The fourth patient had a two year history of Crohn's ileitis which was initially diagnosed by small bowel barium enema and ileoscopy with biopsies. Her symptoms were initially controlled by prednisone and pentasa. She was commenced on azathioprine $100 \mathrm{mg}$ and budesonide $9 \mathrm{mg}$ in July 1997 so as to minimise glucocorticoid side effects. Azathioprine dose was increased to $150 \mathrm{mg}$ after three months and she remained well with good resolution of her symptoms until six months later when she presented with partial small bowel obstruction, melaena, a troublesome cough, and wheeze. Colonoscopy revealed a $6 \mathrm{~cm}$ mass extending from the ileocaecal valve to the ascending colon. Biopsies revealed high grade B cell 
Table 4 Patient details and incidence of cancer among inflammatory bowel disease (IBD) patients in relation to immunosuppressive therapy

\begin{tabular}{llll}
\hline & $\begin{array}{l}\text { Non-immunosuppressive } \\
\text { group }\end{array}$ & Immunosuppressive group & p Value \\
\hline $\mathrm{n}$ & 544 & 238 & \\
Age (y) (mean (SD)) & $46.1(16.7)$ & $39.8(14.3)$ & 0.006 \\
\% Female & $51 \%(277: 267)$ & $56 \%(133: 105)$ & NS \\
\% Crohn's disease & $28 \%$ & $46 \%$ & 0.009 \\
Duration (y) (mean (SD)) & $10.3(7.5)$ & $9.4(5.4)$ & NS \\
All cancers & 16 & 14 & 0.04 \\
Colorectal & 9 & 6 & NS \\
Lymphoma & 0 & 4 & 0.002 \\
Skin & 5 & 2 & NS \\
Others & 2 & 2 & NS \\
\hline
\end{tabular}

$\star$ Unpaired $t$ test.

lymphoma and she underwent a right hemicolectomy. The surgically resected specimen revealed a lead pipe appearance to the terminal ileum, submucosal fibrosis, and granulomata proximal to the lymphoma consistent with underlying Crohn's disease. Computed tomography of the thorax also demonstrated diffuse lung involvement. She successfully tolerated MACOP-B chemotherapy but required a course of CHOP chemotherapy in early 1999 for mediastinal recurrence.

There was a significant excess of all cancers in the immunosuppressive group compared with those IBD patients who did not receive immunosuppressive therapy (14/238 $v$ 16/544; $\mathrm{p}=0.04)$. This was mainly as a result of excess NHL among the immunosuppressive group $(4 / 238 v 0 / 544 ; \mathrm{p}=0.002)$ as there was no significant difference in the incidence of colorectal cancers $(6 / 238 v 9 / 544 ; \mathrm{p}=0.4)$ or skin cancer $(2 / 238 \vee 5 / 544 ; \mathrm{p}=0.9)$ between the groups. These results are summarised in tables 3 and 4.

\section{Discussion}

Our study reports four cases of NHL among 238 IBD patients, all of whom received immunosuppressive therapy, compared with no cases of NHL among the remaining 544 IBD patients who did not receive immunosuppressive therapy. There are a number of possible explanations for the observed increased incidence of NHL in our IBD cohort. Firstly, an excess of intestinal NHL could be expected as a complication of chronic IBD. While an increased risk of colorectal cancer has long been appreciated in IBD patients, particularly patients with longstanding extensive UC, ${ }^{17} 18$ there are also several reports documenting an increased incidence of intestinal, ${ }^{4}$ extraintestinal lymphoma, ${ }^{19}$ and leukaemia ${ }^{20}$ in IBD. Since the association of malignant lymphoma with UC was first reported in $1928,{ }^{21}$ almost 70 cases of IBD complicated by gastrointestinal lymphoma have been reported. ${ }^{22}$ The majority of reported cases predated the use of immunosuppressive therapy, were predominantly left sided high grade B cell NHL, and usually occurred late in the course of extensive longstanding UC (mean duration of colitis at the time of NHL diagnosis 12 years; mean age at NHL diagnosis 50.3 years). ${ }^{22}$ With respect to our second case, although UC patients with primary sclerosing cholangitis are at an increased risk of developing colorectal cancer, ${ }^{23}$ to date only one case of intestinal NHL occurring in a patient with primary sclerosing cholangitis has been described. ${ }^{24}$

Although the relatively small number of cases reported makes it difficult to prove a definite association between IBD and intestinal NHL, variations in the distribution of lymphoma in the normal and inflamed bowel supports such a relationship. Most reported intestinal NHL have arisen at sites of active colitis and the comparative incidence of NHL in different parts of the gut seems to reflect the incidence of Crohn's disease. Cornes and colleagues suggested a significant relationship between repeated episodes of lymphoid hyperplasia seen in the healing phases of UC and the eventual development of NHL. ${ }^{25}$ The "autoimmune" nature of IBD has also been implicated with the suggestion that lymphoma develops as a result of prolonged stimulation of mucosa associated lymphoid tissue. ${ }^{26}$ This "autoimmunity" theory may also explain the 2-3-fold increased risk of NHL in rheumatoid arthritis patients who do not receive immunosuppressive therapy. ${ }^{27} 28$

A second explanation is that of intestinal NHL masquerading as IBD. Although three of the four NHL cases developed in areas of mucosal inflammation ascribed to IBD, the relatively short duration of IBD at the time of diagnosis of lymphoma raises the possibility of intestinal NHL mimicking IBD. The gastrointestinal tract is the commonest site of extranodal lymphoma, ${ }^{29}$ with colorectal lymphomas comprising between $10 \%$ and $20 \%$ of primary gut lymphomas in larger published series. ${ }^{30} 31$ Several reports of primary intestinal lymphoma masquerading as IBD have been described, ${ }^{32} 33$ including a patient with ileocolonic $\mathrm{T}$ cell lymphoma, originally thought to be Crohn's disease at colonoscopy, whose symptoms initially improved on corticosteroids before the correct diagnosis was made nine months later. ${ }^{34}$ However, all NHL cases in our cohort had histological evidence of IBD, either prior to the onset of NHL or in the surgically resected specimens. Furthermore, all were intermediate to high grade lymphomas which tend to run an aggressive rather than an indolent course and as such would be unlikely to present with an insidious course over $2-4.5$ years. However, the possibility of an initially indolent low grade NHL transforming to high grade can not be ruled out.

Because all IBD patients who developed NHL were receiving immunosuppressive therapy, a third explanation is that of immunosuppression related lymphoma. In contrast with "disease" related NHL, excess of immunosuppression related NHL when assessed in transplantation patients is remarkable for its magnitude, its very short induction period (as short as six months in some cases), as well as an unusual predilection for the brain. ${ }^{12133536}$ However, one must be cautious in extrapolating data supporting immunosuppression related NHL from studies which have followed patients after organ transplantation because of the confounding effects of the graft and its foreign antigens. The incidence of immunosup- 
pression related NHL in the absence of organ transplantation has more relevance to IBD patients treated with immunosuppressive drugs. In the largest such study, Kinlen prospectively followed 1634 patients without transplants, including 643 rheumatoid arthritis and 321 IBD patients, 1109 of whom were treated with azathioprine, and found an 11-fold excess of NHL and fivefold excess of squamous cell skin cancer. ${ }^{37}$

The fact that three of our NHL cases were intestinal is also compatible with the effects of immunosuppression, as the gastrointestinal system is the second most frequent site of immunosuppression related NHL. ${ }^{38-40}$ Of note, most non-transplant studies have demonstrated that immunosuppression related NHL does not show the same predilection for the brain as those in transplant recipients. Furthermore, in the setting of immunosuppression, it is interesting to note that Crohn's tissue homogenates have been reported to induce B cell lymphomas in athymic mice suggesting, at least in experimental animals, a link between Crohn's disease, immunosuppression, and malignant lymphoma. ${ }^{41}$ In addition, three of our four cases were large cell diffuse B cell lymphomas, which are by far the commonest type of immunosuppression induced lymphoma described. ${ }^{42}$

Because immunosuppressed IBD patients have an increased susceptibility to infection, particularly from Ebstein-Barr virus, cytomegalovirus, and herpes zoster, ${ }^{12}$ malignant transformation secondary to pre-existing viral infection has been postulated to explain the short induction period. Of note, our second patient had mucosal evidence of superimposed cytomegalovirus infection preceding the development of colonic lymphoma. Data linking Helicobacter pylori infection with the development of low grade B cell gastric lymphoma, with regression of lymphoma following eradication of the organism, illustrate how antigenic stimulation secondary to infection can result in growth and possibly development of lymphoma. ${ }^{43}$ Because a 59-fold excess of NHL among our immunosuppressive group is certainly not typical of immunosuppression related NHL reported in other non-transplant patients, and the number of cases is small, the possibility of a type II error cannot be discounted. However, this would not explain the fact that all NHL cases occurred only in patients who received immunosuppressive drugs.

While two of our cases occurred in patients receiving azathioprine, the remaining cases occurred in patients receiving low dose methotrexate, one of whom subsequently received cyclosporin. Cyclosporin treatment of other autoimmune diseases has been found to cause a slight increase in the incidence of NHL to approximately $0.3 \%,{ }^{44}{ }^{45}$ while cases of NHL have been reported in patients with rheumatoid arthritis receiving low dose weekly methotrexate, ${ }^{46}{ }^{47}$ including a report of Ebstein-Barr virus associated lymphoma which resolved after discontinuation of low dose methotrexate. ${ }^{48}$ However, prior to our experi- ence, NHL has not been reported in IBD patients treated with either of these agents or in patients with rhematoid arthritis treated with a combination of methotrexate and cyclosporin. ${ }^{49}$ While this may reflect the relatively low malignant potential of these agents compared with azathioprine, the power of any study necessary to detect an increased risk is limited by the relatively small numbers of patients who receive these agents in contrast with azathioprine, as well as the relative lack of follow up, particularly in the case of UC patients who often undergo proctocolectomy within months of commencing cyclosporin. However, development of NHL in two of 31 IBD patients who received methotrexate therapy is worrying and suggests that for a small cohort of IBD patients, the combination of an underlying aggressive "autoimmune" disease and immunosuppressive therapy may be more significant in the development of lymphoproliferative disease than previously appreciated. For example, all four rheumatoid arthritis patients who developed lymphoproliferative disease following infliximab therapy had also received oral methotrexate, including two patients who had received azathioprine therapy prior to referral for infliximab. ${ }^{15}$ Similarly, both Crohn's disease patients who developed NHL following infliximab infusions had also received azathioprine for refractory disease. ${ }^{15}$ While the numbers of reported cases are small relative to the vast number of patients who have received immunosuppressive drugs to date, the possibility exists that cumulative exposure to a single or multiple immunosuppressive agents may combine in a small subset of patients with aggressive disease to significantly increase their risk of NHL. It is therefore prudent to observe IBD patients whose disease requires treatment with immunosuppressive agents, including azathioprine, methotrexate, cyclosporin, and infliximab, for the development of NHL

In conclusion, despite the small power of our study, we detected four cases of NHL in IBD patients who received immunosuppressive therapy. While acknowledging that underlying IBD may be a significant causal factor in the development of intestinal NHL, our experience demonstrates that azathioprine therapy, as well as methotrexate and cyclosporin, may not only have predisposed to, but also accelerated the development of NHL in these IBD patients. Although the relative risk of NHL in IBD patients receiving immunosuppressive therapy is high, the overall absolute risk of IBD patients in our cohort developing NHL remains quite small at $0.06 \%$ per patient-years. Thus the risk of NHL must be weighed against the improved quality of life and clinical benefit immunosuppressive therapy provides for IBD patients.

1 Hoover R, Fraumeni JF. Risk of cancer in renal-transplant recipients. Lancet 1973,ii:55-7.

2 Kinlen LJ, Sheil AGR, Peto J, et al. Collaborative United Kingdom-Australasian study of cancer in patients treated with immunosuppressive drugs. BMF 1979;ii:1461-6.

3 Greenstein AJ, Gennuso R, Sachar DB, et al. Extraintestinal cancers in inflammatory bowel disease. Cancer 1985;56: 2914-21. 
4 Shepherd NA, Hall PA, Williams GT, et al. Primary malignant lymphoma of the large intestine complicating chronic inflam.

5 Renton P, Blackshaw AJ. Colonic lymphoma complicating ulcerative colitis. Br f Surg 1976;63:542-5.

6 Wychulis AR, Beahrs $\mathrm{OH}$, Woolner LB. Malignant lymphoma of the colon. A study of 69 cases. Arch Surg 1966;93:215-25.

7 Ekbom A, Helmick C, Zack M, et al. Extracolonic malignancies in inflammatory bowel disease. Cancer 1991; 67:2015-19.

8 Persson PG, Karlen P, Bernell O, et al. Crohn's disease and cancer: a population based cohort study. Gastroenterology 1994;107:1675-79.

9 Loftus EV, Sandborn WJ, Tremaine WJ, et al. Risk of lymphoma in inflammatory bowel disease: a population estimate. Gastroenterology 1998;114:A1024.

10 Connell WR, Kamm MA, Dickson, et al. Long-term neoplasia risk after azathioprine treatment in inflammatory neoplasia risk after azathioprine treatmen
bowel disease. Lancet 1994;343:1249-52.

11 Lemann M, Bonhomme P, Bitoun A, et al. Treatment of Crohn's disease with azathioprine or 6-mercaptopurine. Retrospective study of 126 cases. Gastroenterol Clin Biol 1990;14:548-54.

12 Present DH, Meltzer SJ, Krumholz MP, et al. 6-Mercaptopurine in the management of inflammatory bowel disease: Short- and long-term toxicity. Ann Intern Med 1989;111:641-49.

13 Kinlen LJ. Immunologic factors, including AIDS. In: Schottenfeld D, Fraumeni JF Jr, eds. Cancer epidemiology and prevention, 2nd edn. New York: Oxford University Press, 1996:532-45.

14 Bouhnik Y, Lemann M, Mary JY, et al. Long-term follow-up of patients with Crohn's disease treated with azathioprine or 6-mercaptopurine. Lancet 1996;347:215-19.

15 Bickston SJ, Lichtenstein GR, Arseneau KO, et al. The relationship between infliximab treatment and lymphoma in tionship between infliximab treatment and lymphom

16 Cancer in Ireland. 1995 incidence and mortality. National Cancer Registry of Ireland, 1996.

17 Edwards FC, Truelove SG. The course and prognosis of ulcerative colitis. Gut 1964;5:1-22.

18 Ekbom A, Helmick E, Zack M, et al. Ulcerative colitis and colorectal cancer. A population based study. $N$ Engl F Med 1990;323:1228-33

19 Greenstein AJ, Mullin GE, Strauchen JA, et al. Lymphoma in inflammatory bowel disease. Cancer 1992;69:1119-23.

20 Caspi O, Polliack A, Klar R, et al. The association of inflammatory bowel disease and leukemia-coincidence or not? Leuk Lymphoma 1995;17:255-62.

21 Bargen JA. Chronic ulcerative colitis associated with malignant disease. Arch Surg 1928;93:1307-11.

22 Lenzen R, Borchard F, Lubke $\mathrm{H}$, et al. Colitis ulcerosa complicated by malignant lymphoma: case report and analysis of published works. Gut 1995;36:306-10.

23 Shetty K, Rybicki L, Brzezinski A, et al. The risk for cancer or dysplasia in ulcerative colitis patients with primary scleor dysplasia in ulcerative colitis patients with primary

24 Schattner A, Kozak N, Lassry Y, et al. Primary intestinal T-cell lymphoma and sclerosing cholangitis: a cytokinemediated association? F Intern Med 1998;244:537-41.

25 Cornes JS, Smith JC, Southwood WFW. Lymphosarcoma in chronic ulcerative colitis with report of two cases. Br F Surg 1961;49:50-3.

26 Sataline LR, Mosley EM, Kirkham W. Ulcerative colitis complicated by colonic lymphoma. Gastroenterology 1962 44:342-7.

27 Isomaki HA, Hakulinen T, Joutsenlahti U. Excess risk of lymphoma, leukemia, and myeloma in patients with rheumatoid arthritis. $\mathcal{F}$ Chronic Dis 1978;31:691-6.
28 Gridley G, McLaughlin JK, Ekbom A, et al. Incidence of cancer among patients with rheumatoid arthritis. 7 Natl cancer among patients with
Cancer Inst 1993;85:307-11.

29 Freeman C, Berg JW, Cutler SJ. Occurrence and prognosis of extranodal lymphomas. Cancer 1972;29:252-60.

30 Loehr WJ, Mujahed Z, Zahn FD, et al.. Primary lymphoma of the gastrointestinal tract: a review of 100 cases. Ann Surg 1969;170:232-8.

31 Dragosics B, Bauer P, Radaszikiewicz T. Primary gastrointestinal non-Hodgkin's lymphomas. A retrospective clinico-pathological study of 150 cases. Cancer 1985;55: 1060-73.

32 Friedman HB, Silver GM, Brown CH. Lymphoma of the colon simulating ulcerative colitis: report of four cases. $\mathrm{Am}$ F Dig Dis 1968;13:910-17.

33 Robert ME, Kuo FC, Longtine JA, et al. Diffuse colonic mantle cell lymphoma in a patient with presumed ulcerative colitis. Am f Surg Pathol 1996;20:1024-31.

34 Son HJ, Rhee PL, Kim JJ, et al. Primary T-cell lymphoma of the colon. Korean f Int Med 1997;12:238-41.

35 Gelb A, Zalusky R. Lymphoma in Crohn's disease occurring in a patient on 6-MP. Am f Gastroenterol 1983;78:316

36 Kingsmore SF, Hall BD, Allen NB, et al. Association of methotrexate, rheumatoid arthritis and lymphoma: Report of 2 cases and literature review. F Rheum 1992;19:1462-5.

37 Kinlen LJ. Incidence of cancer in rheumatoid arthritis and other disorders after immunosuppressive treatment. $A m \mathcal{F}$ Med 1985;78(suppl 1a):44-9.

38 Jones M, Symmons D, Finn J, et al. Does exposure to immunosuppressive therapy increase the 10 year malignancy and mortality risks in rheumatoid arthritis? A matched cohort study. Br f Rheum 1996;35:738-45.

39 Ziegler JL, Beckstead JA, Volberding PA, et al. NonHodgkin's lymphoma in 90 homosexual men. Relation to generalized lymphadenopathy and the acquired immunogeneralized lymphadenopathy and the acquired immuno
deficiency syndrome. $N$ Engl F Med 1984;311:565-70.

40 Burkes RL, Meyer PR, Gill PS, et al. Rectal lymphoma in homosexual men. Arch Intern Med 1986;29:413-16.

41 Das KM, Valenzuela I, Morecki R. Crohn disease lymph node homogenates produce murine lymphoma in athymic mice. Proc Natl Acad Sci USA 1980;77:588-92.

42 Cleary GL, Warnke R, Sklar J. Monoclonality of lymphoproliferative lesions in cardiac transplant recipients. $N$ Engl $\mathcal{F}$ Med 1984;310:477-82.

43 Hussell T, Isaacson PG, Crabtree JE, et al. The response of cells from low grade B-cell gastric lymphoma of mucosaassociated lymphoid tissue to Helicobacter pylori. Lancet 1993;342:571-4.

44 Sandborn WJ. A review of immune modifier therapy for inflammatory bowel disease: azathioprine, 6-mercaptopurine, cyclosporine, and methotrexate. Am $\mathcal{F}$ Gastroenterol 1996;91:423-33.

45 Cockburn IT, Krupp P. The risk of neoplasms in patients treated with cyclosporine A. F Autoimmun 1989;2:723-31.

46 Ellman $\mathrm{MH}$, Hurwitz $\mathrm{H}$, Thomas $\mathrm{C}$, et al. Lymphoma developing in a patient with rheumatoid arthritis taking low dose weekly methotrexate. F Rheumatol 1991;18:1741-3.

47 Bailin PL, Tindall JP, Roenigk HH, et al. Is methotrexate therapy for psoriasis carcinogenic? fAMA 1975;232:35962.

48 Kamel OW, Van de Rijn M, Weissl M, et al. Reversible lymphoma associated with Epstein-Barr virus occurring during methotrexate therapy for rheumatoid arthritis and dermatomyositis. N Engl f Med 1993;328:1317-21

49 Stein CM, Pincus T, Yocum D, et al. Combination treatment of severe rheumatoid arthritis with cyclosporine and methotrexate for forty-eight weeks: an open-label extension study. The Methotrexate-Cyclosporine Combination Study Group. Arthritis Rheum 1997;40:1843-51. 